\title{
Appel à candidature / Call for Nominations
}

\author{
Traduction annuelle $S d B S 2021$ \\ Date limite : 1 février 2020
}

Connaissez-vous un article ou un chapitre de livre déjà publié qui constitue un exemple d'érudition remarquable, mais qui n' a pas encore reçu l'attention interdisciplinaire et internationale qu'il mérite? En accord avec sa mission de promotion des échanges interculturels et internationaux, la revue Simone de Beauvoir Studies sélectionne chaque année un article ou un chapitre déjà publié et le traduit en anglais ou en français afin de souligner son importance pour le domaine de recherche dans lequel il s'inscrit et d'étendre son lectorat. Les articles ou chapitres de livre éligibles doivent avoir été publiés antérieurement dans une langue autre que l'anglais et comprendre environ 10000 mots. Pour découvrir comment soumettre une candidature, nous vous invitons à consulter l' onglet «About/Downloads» de la page suivante : www.brill.com/ sdbs. Vous y trouverez les « Consignes pour les recommandations de traduction annuelle ».

\section{SdBS Featured Translation 2021}

Deadline: February 1, 2020

Do you know of a previously published article or book chapter that is an exemplar of outstanding scholarship but has not yet received the international and interdisciplinary attention that it deserves? Consistent with its mission of promoting international and cross-cultural exchange, Simone de Beauvoir Studies selects one article-length work per year that has already been published and translates it into either English or French in order to emphasize its significance to the field and increase its readership. Eligible works are any article or book chapter (ideally less than 10,000 words) that was published recently or long ago in any language other than English. For more information, please see "Translation Nomination Guidelines" under the About/Downloads tab at www .brill.com/sdbs. 